\title{
Scratching the Surface of Possible Translations
}

Ondřej Bojar Matouš Macháček Aleš Tamchyna Daniel Zeman

Charles University in Prague, Faculty of Mathematics and Physics Institute of Formal and Applied Linguistics (ÚFAL)

TSD 2013

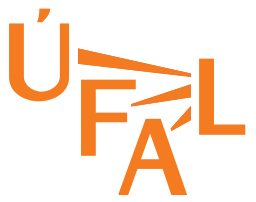




\section{Outline}

(1) Introduction

(2) Compact Representations for Many References

(3) Collected Data

(4) Analysis

(5) Conclusion 
Introduction 


\section{Introduction}

Broad perspective:

- Relation between sentence meaning and the string is complicated.

- Many variations of a sentence preserve the meaning.

- A little change in a word can drastically reverse the meaning.

- We want a tangible dataset that represents this relation. 


\section{Introduction}

Broad perspective:

- Relation between sentence meaning and the string is complicated.

- Many variations of a sentence preserve the meaning.

- A little change in a word can drastically reverse the meaning.

- We want a tangible dataset that represents this relation.

Narrow use case:

- Machine translation is evaluated by comparing output to a reference.

- There are many good translations of a sentence

- Only very few of them are available as a reference translation.

- We want to improve MT evaluation using more/all references. 


\section{Space of Possible Translations}

For a single English source sentence, we can consider:

All sequences of Czech words 


\section{Space of Possible Translations}

For a single English source sentence, we can consider:

All sequences of Czech words

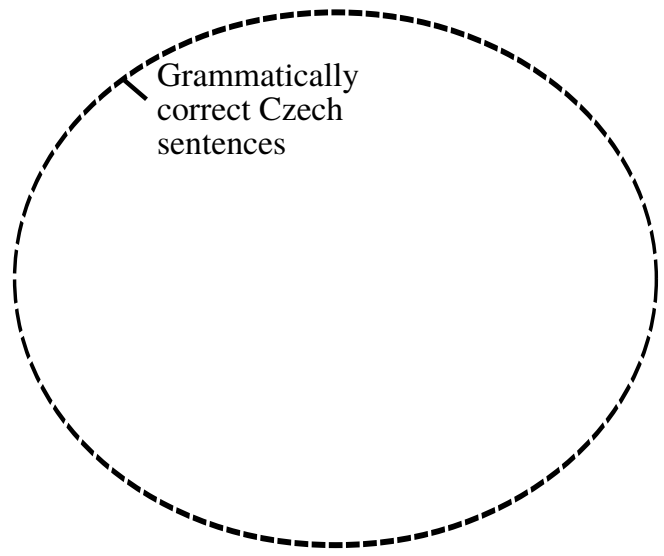




\section{Space of Possible Translations}

For a single English source sentence, we can consider:

All sequences of Czech words

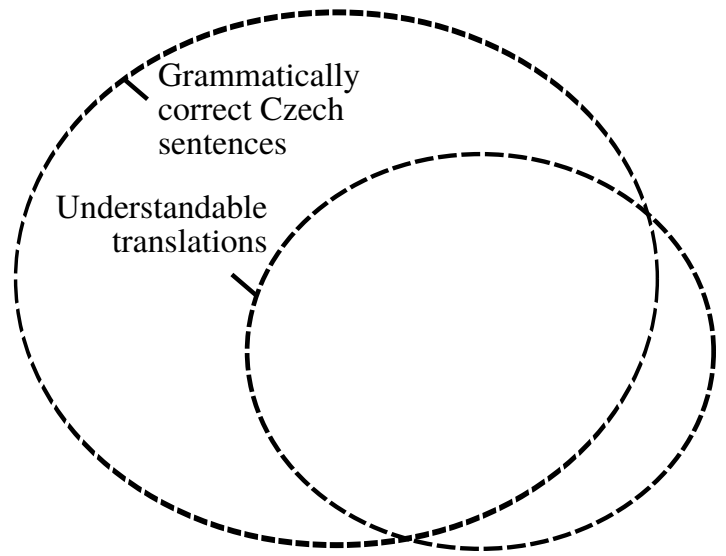




\section{Space of Possible Translations}

For a single English source sentence, we can consider:

All sequences of Czech words

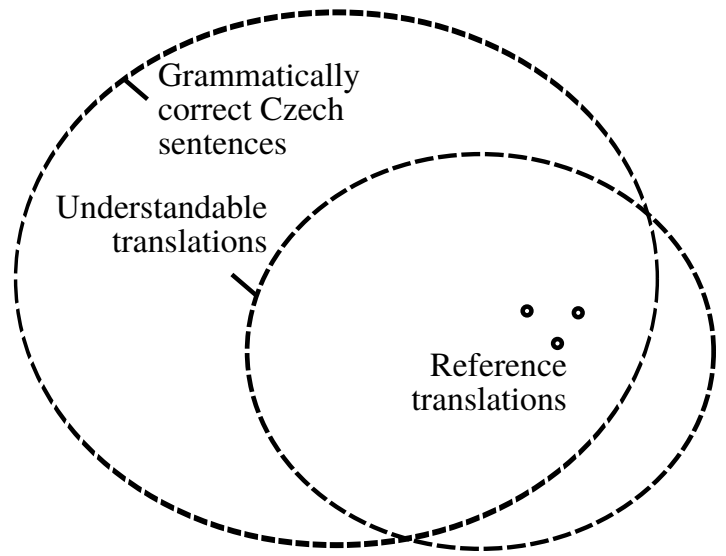




\section{Space of Possible Translations}

For a single English source sentence, we can consider:

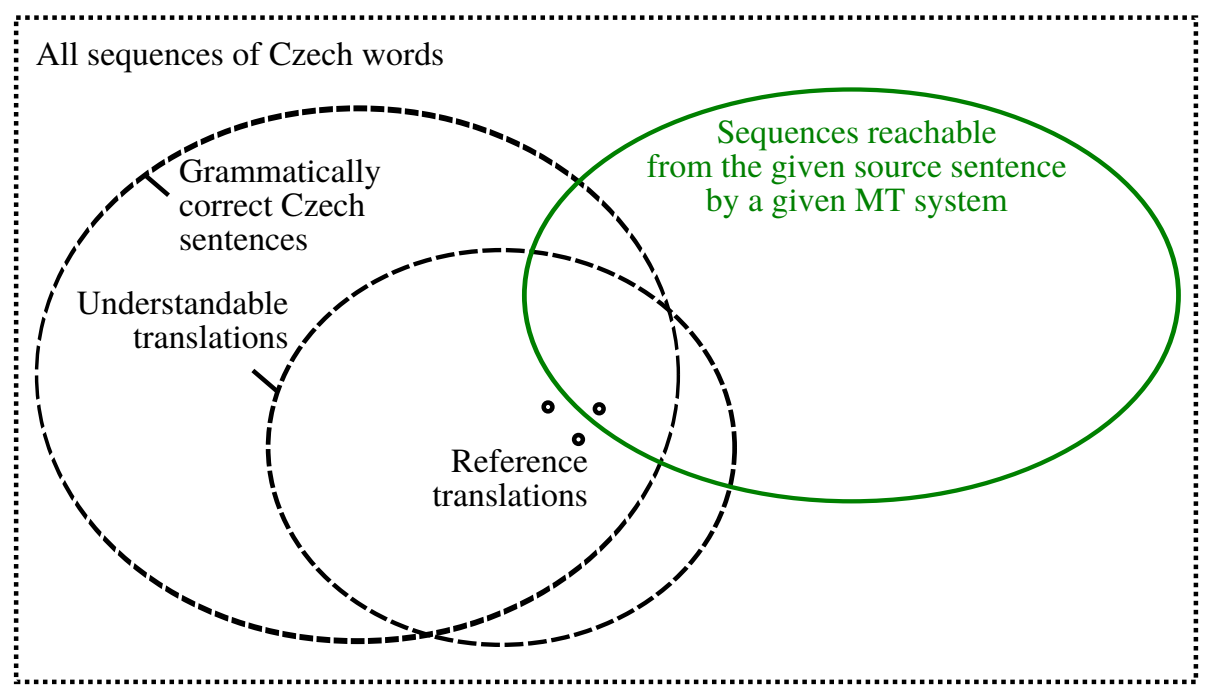




\section{Space of Possible Translations}

For a single English source sentence, we can consider:

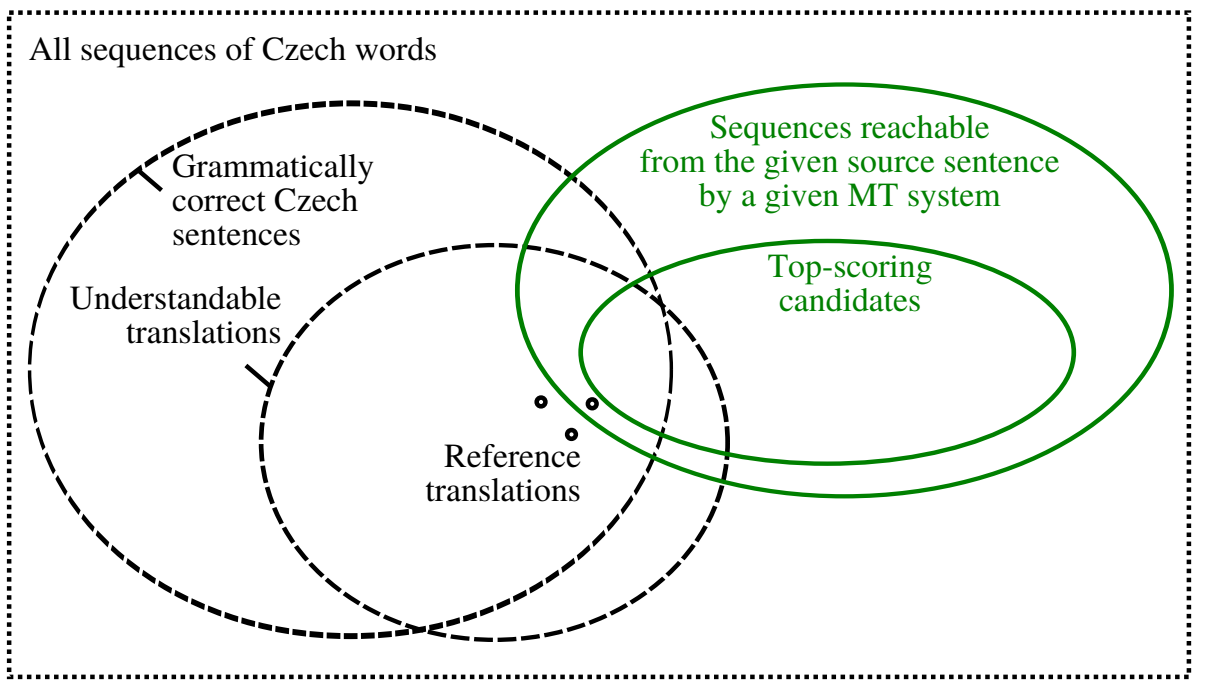




\section{Space of Possible Translations}

For a single English source sentence, we can consider:

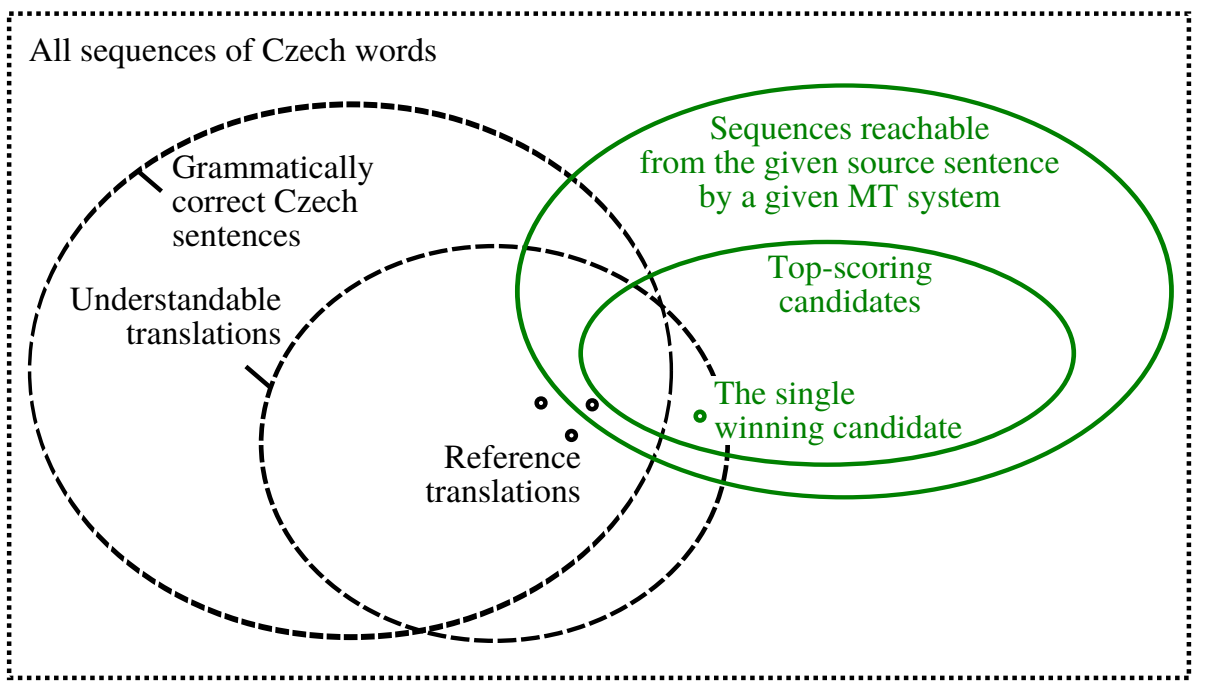




\section{Space of Possible Translations}

For a single English source sentence, we can consider:

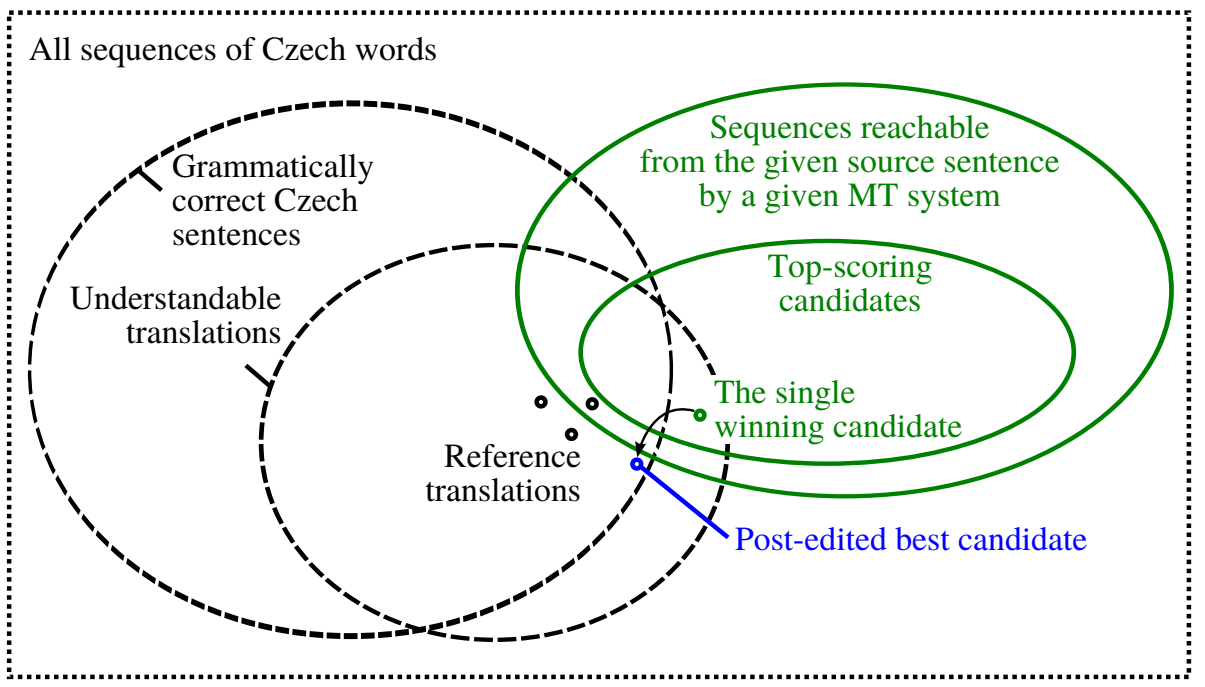




\section{Space of Possible Translations}

For a single English source sentence, we can consider:

All sequences of Czech words

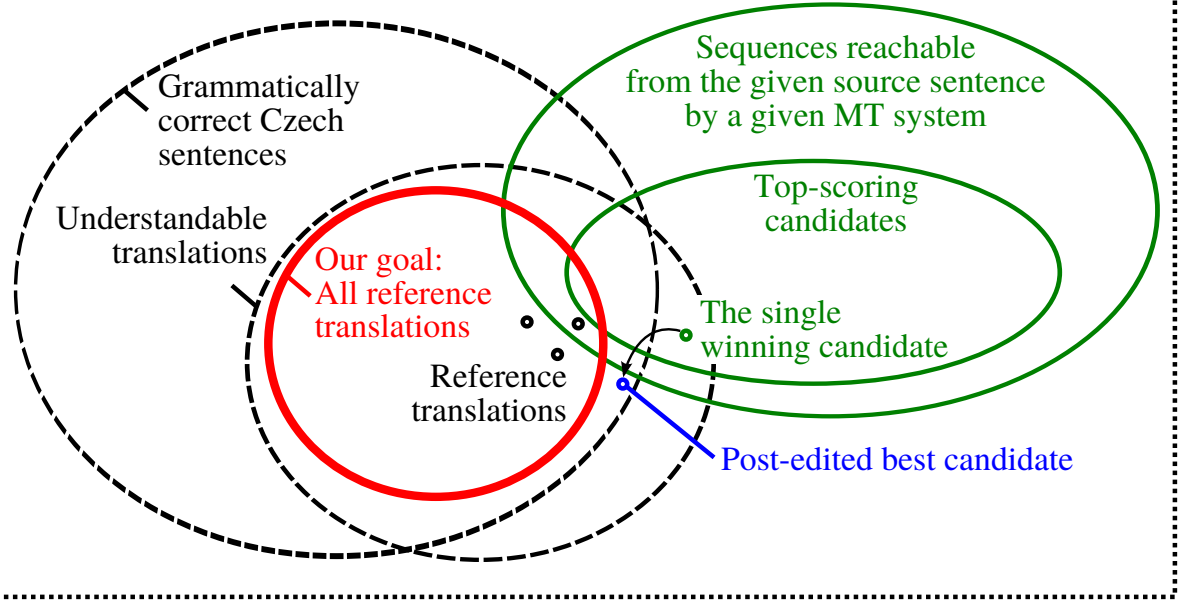




\section{Compact Representation of Many References}

- Typing out all references is not possible. 


\section{Compact Representation of Many References}

- Typing out all references is not possible.

- Dreyer and Marcu (2012) use Recursive Transition Networks (RTN). 


\section{Compact Representation of Many References}

- Typing out all references is not possible.

- Dreyer and Marcu (2012) use Recursive Transition Networks (RTN). - An RTN consists of cards: 


\section{Compact Representation of Many References}

- Typing out all references is not possible.

- Dreyer and Marcu (2012) use Recursive Transition Networks (RTN).

- An RTN consists of cards:

- A card covers multiple translations of a short phrase:

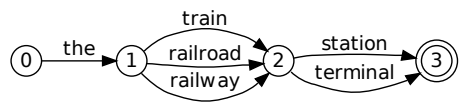




\section{Compact Representation of Many References}

- Typing out all references is not possible.

- Dreyer and Marcu (2012) use Recursive Transition Networks (RTN).

- An RTN consists of cards:

- A card covers multiple translations of a short phrase:

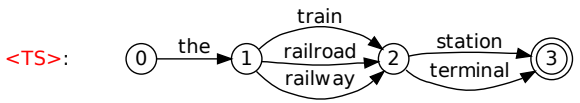

- Cards are reused within other cards to built the sentence:

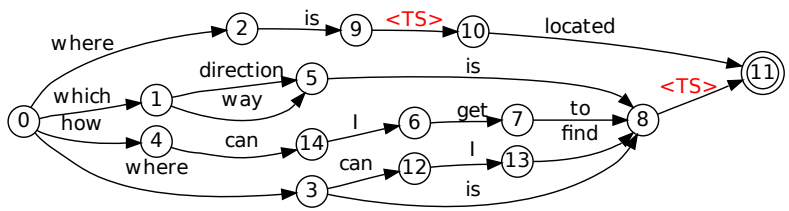




\section{Recursive Transition Networks for Czech}

The city council approved a new regulation. 


\section{Recursive Transition Networks for Czech}

The city council approved new regulation 


\section{Recursive Transition Networks for Czech}
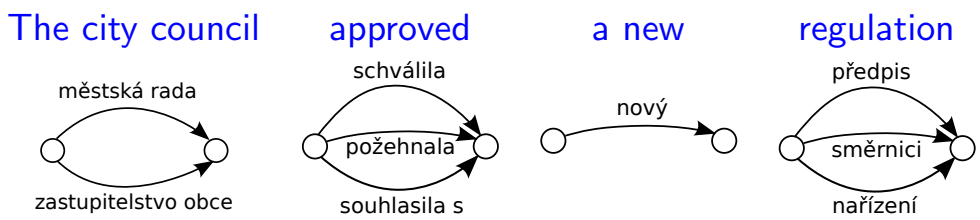


\section{Recursive Transition Networks for Czech}

The city council approved a new regulation.

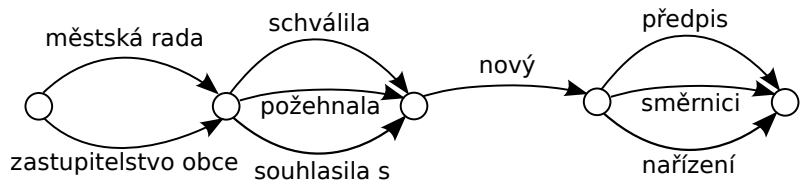




\section{Recursive Transition Networks for Czech}

The city council approved a new regulation.

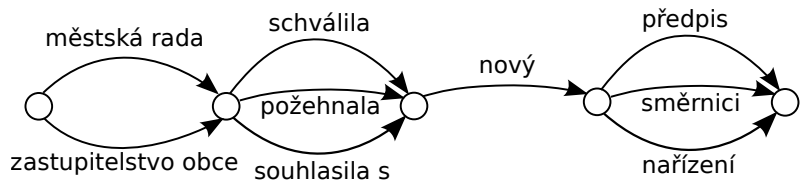

Městská rada schválila nový předpis 


\section{Recursive Transition Networks for Czech}

The city council approved a new regulation.

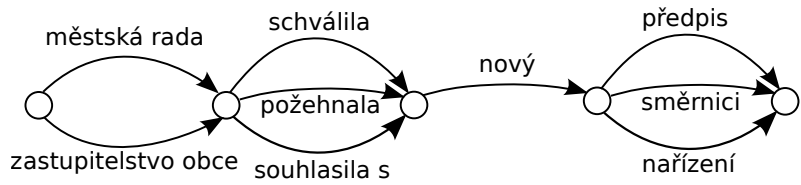

Městská rada schválila nový předpis 


\section{Recursive Transition Networks for Czech}

The city council approved a new regulation.

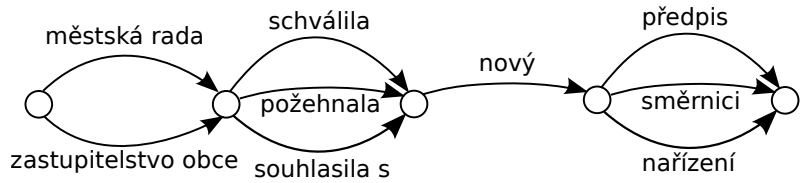

Městská rada schválila nový předpis

Zastupitelstvo $_{\text {neut }}$ obce schválila fem nový předpis 


\section{Recursive Transition Networks for Czech}

The city council approved a new regulation.

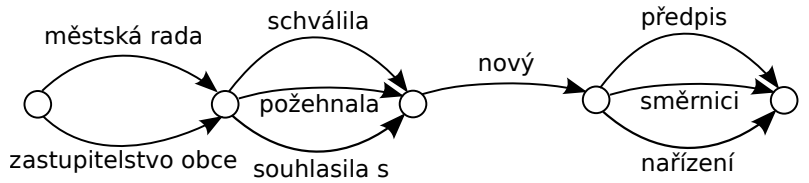

Městská rada schválila nový předpis

Zastupitelstvo $_{\text {neut }}$ obce schválila fem nový předpis 


\section{Recursive Transition Networks for Czech}

The city council approved a new regulation.

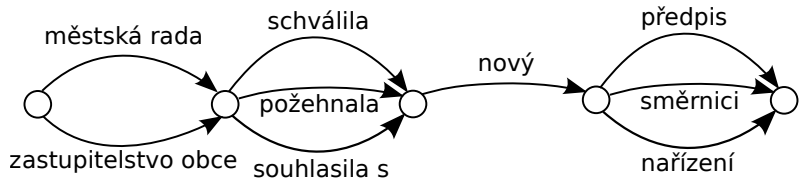

Městská rada schválila nový předpis

Zastupitelstvo $_{\text {neut }}$ obce schválila fem nový předpis

Městská rada schválila novýmasc směrnici $_{f e m}$ 


\section{Recursive Transition Networks for Czech}

The city council approved a new regulation.

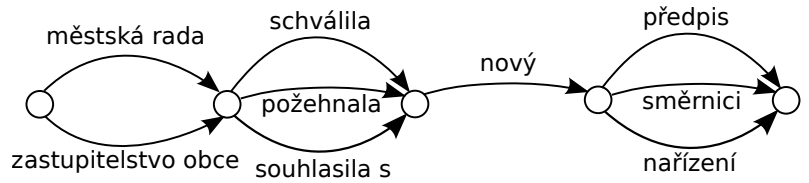

Městská rada schválila nový předpis

Zastupitelstvo $_{\text {neut }}$ obce schválila fem nový předpis

Městská rada schválila novýmasc směrnici $_{f e m}$ 


\section{Recursive Transition Networks for Czech}

The city council approved a new regulation.

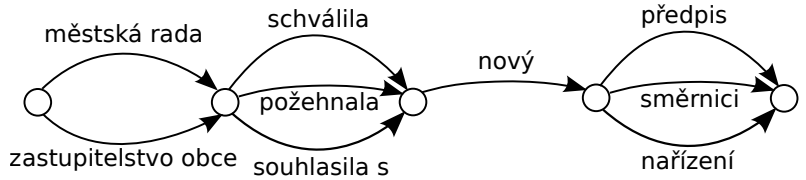

Městská rada schválila nový předpis

Zastupitelstvo $_{\text {neut }}$ obce schválila fem nový předpis

Městská rada schválila novýmasc směrnici ${ }_{f e m}$

Městská rada souhlasilarequires ins nový předpis ${ }_{\text {nom }}$ 


\section{Recursive Transition Networks for Czech}

The city council approved a new regulation.

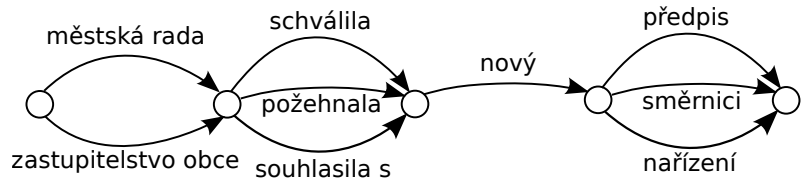

Městská rada schválila nový předpis

Zastupitelstvo $_{\text {neut }}$ obce schválila fem nový předpis

Městská rada schválila novýmasc směrnici ${ }_{f e m}$

Městská rada souhlasilarequires ins nový předpis ${ }_{\text {nom }}$ 


\section{Recursive Transition Networks for Czech}

The city council approved a new regulation.

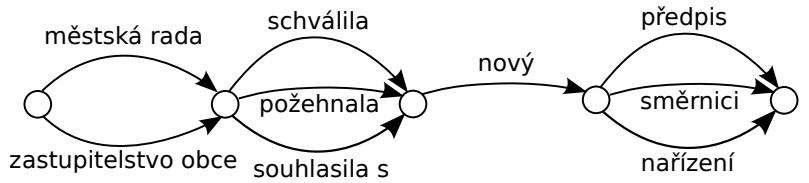

Městská rada schválila nový předpis

Zastupitelstvo $_{\text {neut }}$ obce schválila fem nový předpis

Městská rada schválila novýmasc směrnici $_{f e m}$

Městská rada souhlasilarequires ins nový předpis

- Czech needs to specify constraints under which cards can combine. 


\section{Recursive Transition Networks for Czech}

The city council approved a new regulation.

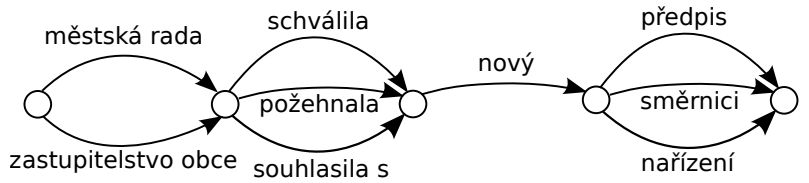

Městská rada schválila nový předpis

Zastupitelstvo $_{\text {neut }}$ obce schválila fem nový předpis

Městská rada schválila novýmasc směrnici $_{f e m}$

Městská rada souhlasilarequires ins nový předpis

- Czech needs to specify constraints under which cards can combine.

- The workaround of using many card types would be cumbersome. 


\section{Unification-Based Annotation}

- We proposed a unification-based representation suitable for Czech. 


\section{Unification-Based Annotation}

- We proposed a unification-based representation suitable for Czech.

- Main building block called bubble, defined by: 


\section{Unification-Based Annotation}

- We proposed a unification-based representation suitable for Czech.

- Main building block called bubble, defined by:

- The set of source language tokens it covers 


\section{Unification-Based Annotation}

- We proposed a unification-based representation suitable for Czech.

- Main building block called bubble, defined by:

- The set of source language tokens it covers

- The set of conditions it meets 


\section{Unification-Based Annotation}

- We proposed a unification-based representation suitable for Czech.

- Main building block called bubble, defined by:

- The set of source language tokens it covers

- The set of conditions it meets

- A translation alternative, composed of:

- atoms - tokens of the target language

- slots - positions with given conditions which bubbles must fulfil to fill the slot 


\section{Bubble Annotation}

- Input: John loves Mary.

- Annotation $=$ bubbles covering parts of input.

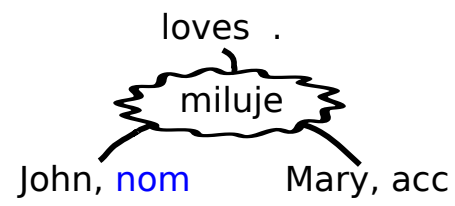




\section{Bubble Annotation}

- Input: John loves Mary.

- Annotation $=$ bubbles covering parts of input.

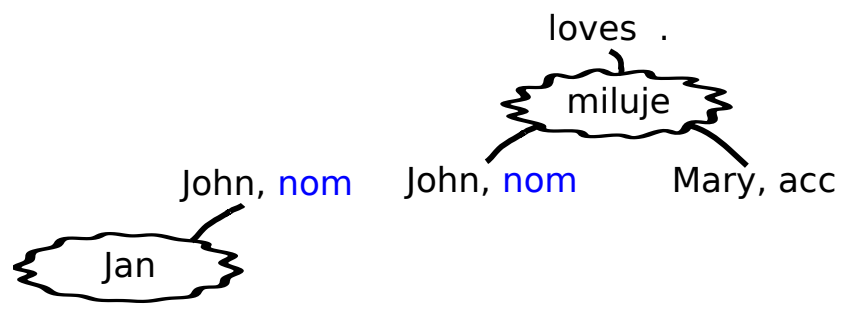




\section{Bubble Annotation}

- Input: John loves Mary.

- Annotation $=$ bubbles covering parts of input.

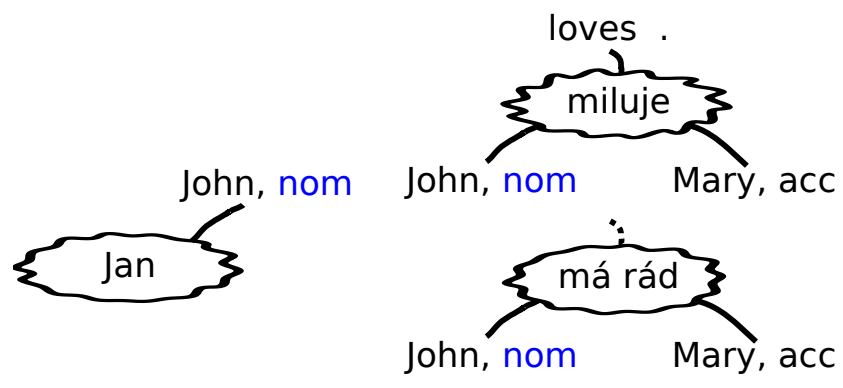




\section{Bubble Annotation}

- Input: John loves Mary.

- Annotation $=$ bubbles covering parts of input.

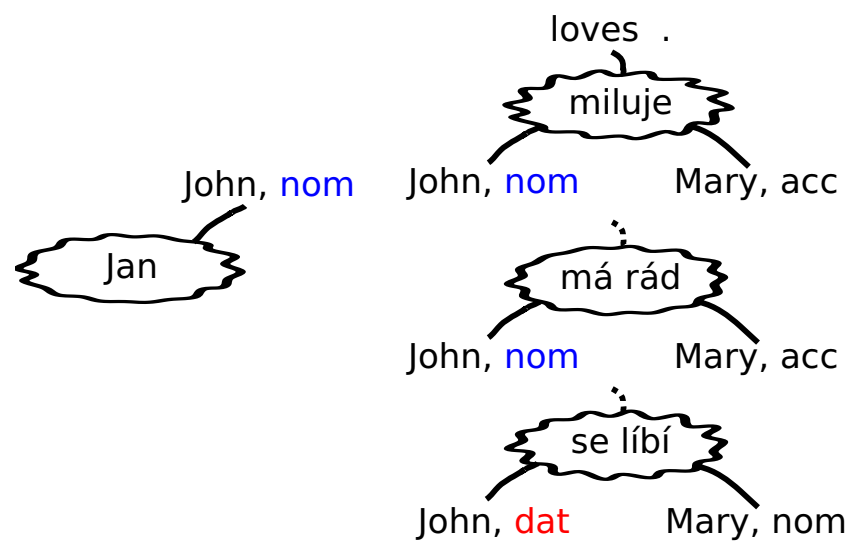




\section{Bubble Annotation}

- Input: John loves Mary.

- Annotation $=$ bubbles covering parts of input.

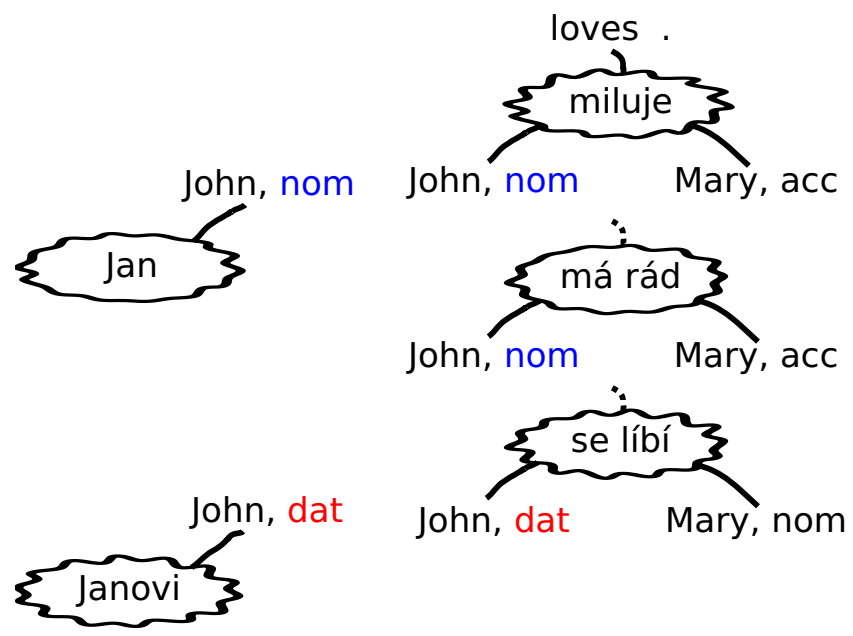




\section{Annotating Translations: Prolog Interface}

- Prolog is ideal for constraints evaluation and bubble expansion. 


\section{Annotating Translations: Prolog Interface}

- Prolog is ideal for constraints evaluation and bubble expansion.

- The annotator specifies a set of bubbles as clauses for option/2. 


\section{Annotating Translations: Prolog Interface}

- Prolog is ideal for constraints evaluation and bubble expansion.

- The annotator specifies a set of bubbles as clauses for option/2.

$$
\begin{aligned}
& \text { this this this bubble } \\
& \text { option( bubble, bubble, provides and ). } \\
& \text { covers safisfies requires }
\end{aligned}
$$




\section{Annotating Translations: Prolog Interface}

- Prolog is ideal for constraints evaluation and bubble expansion.

- The annotator specifies a set of bubbles as clauses for option/2.

$$
\begin{aligned}
& \text { this this this bubble } \\
& \text { option( bubble, bubble, provides and ). } \\
& \text { covers safisfies requires }
\end{aligned}
$$

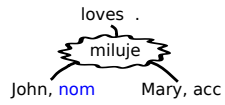




\section{Annotating Translations: Prolog Interface}

- Prolog is ideal for constraints evaluation and bubble expansion.

- The annotator specifies a set of bubbles as clauses for option/2.

\begin{tabular}{|c|c|c|c|c|}
\hline & option( & $\begin{array}{l}\text { this } \\
\text { bubble } \\
\text { covers }\end{array}$ & $\begin{array}{c}\text { this } \\
\text { bubble } \\
\text { safisfies }\end{array}$ & $\begin{array}{c}\text { this bubble } \\
\text { provides and } \\
\text { requires }\end{array}$ \\
\hline$\underbrace{\text { loves }}_{\text {lohn, nom Mary, acc }}$ & option ( & [loves, & .],[]$, & $\begin{array}{c}{[\text { John, nom }],} \\
\text { miluje, } \\
[\text { Mary, acc }]]\end{array}$ \\
\hline
\end{tabular}




\section{Annotating Translations: Prolog Interface}

- Prolog is ideal for constraints evaluation and bubble expansion.

- The annotator specifies a set of bubbles as clauses for option/2.

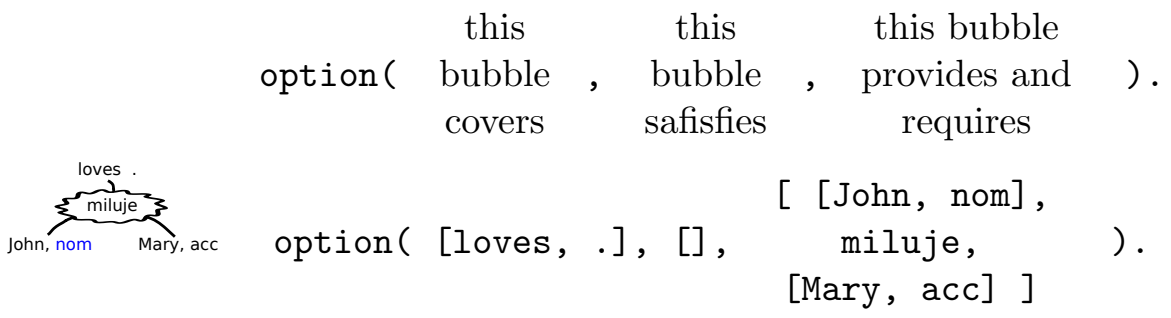

John, dat

Janovi 


\section{Annotating Translations: Prolog Interface}

- Prolog is ideal for constraints evaluation and bubble expansion.

- The annotator specifies a set of bubbles as clauses for option/2.

$$
\begin{aligned}
& \text { this this this bubble } \\
& \text { option( bubble, bubble, provides and ). } \\
& \text { covers safisfies requires }
\end{aligned}
$$

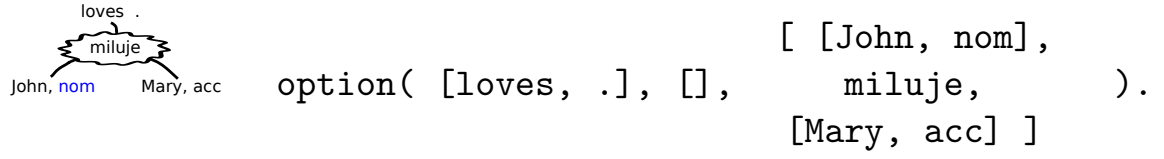

$$
\begin{aligned}
& \text { option( [John], [dat], [Janovi]). }
\end{aligned}
$$




\section{Annotating Translations: Prolog Interface}

- Prolog is ideal for constraints evaluation and bubble expansion.

- The annotator specifies a set of bubbles as clauses for option/2.

$$
\begin{aligned}
& \text { this this this bubble } \\
& \text { option( bubble, bubble, provides and ). } \\
& \text { covers safisfies requires }
\end{aligned}
$$

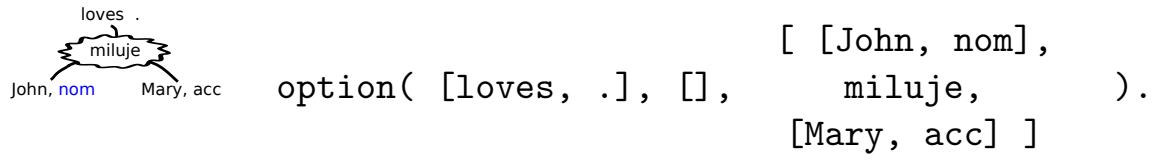

$$
\begin{aligned}
& \text { option( [John], [dat], [Janovi]). }
\end{aligned}
$$

- About 300 lines of a common code generates all possible sentences. 


\section{Web Interface}

- Editing prolog source code is not for everyone. 


\section{Web Interface}

- Editing prolog source code is not for everyone.

- Our web-based graphical interface hides away the Prolog syntax: 


\section{Web Interface}

- Editing prolog source code is not for everyone.

- Our web-based graphical interface hides away the Prolog syntax:

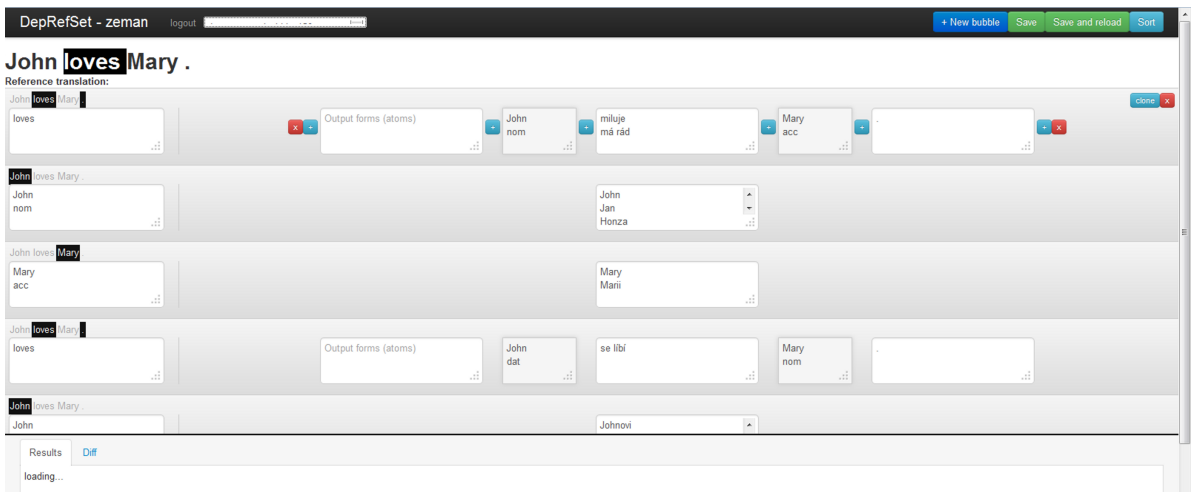




\section{Web Interface}

- Editing prolog source code is not for everyone.

- Our web-based graphical interface hides away the Prolog syntax:
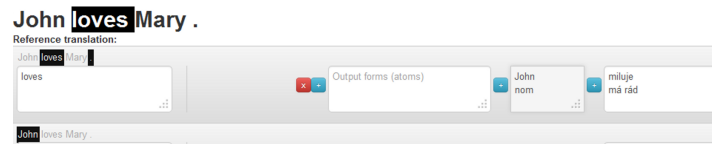

\begin{tabular}{|l|l|l|}
\hline+ New bubble & Save Save and reload Sort \\
\hline
\end{tabular}

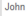

John
nom

John love: Mary

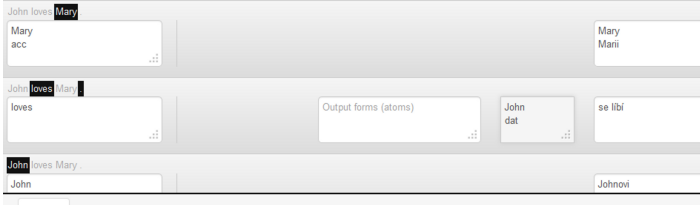

Results Diff 


\section{Web Interface}

John |OVes |Vlary . Reference translation:

John loves Mary.

loves

John loves Mary

Bojar et al. (ÚFAL) 


\section{Web Interface}

John

nom

\section{miluje \\ má rád}




\section{Web Interface}

John

\section{se líbí}

dat

\section{Johnovi}

Bojar et al. (ÚFAL)
Scratching the Surface of Possible Trans.

TSD 2013

$10 / 16$ 


\section{Collected Data}

- We selected 50 sentences from the WMT11 test set for annotation 


\section{Collected Data}

- We selected 50 sentences from the WMT11 test set for annotation

- 6 translators involved in the task, producing 77 sets of references

- 24 sentences translated by one anotator

- 25 sentences translated by two anotators

- 1 sentence transalted by three anotators 


\section{Collected Data}

- We selected 50 sentences from the WMT11 test set for annotation

- 6 translators involved in the task, producing 77 sets of references

- 24 sentences translated by one anotator

- 25 sentences translated by two anotators

- 1 sentence transalted by three anotators

- Combined with other translations of WMT11 test set, we have:

Label Reference set

O The single official reference translation of WMT11

P Manual post-edits of a phrase-based MT system

D Our many references
Sent. Refs.

$\begin{array}{cc}3003 & 1 \\ 1997 & 2 \\ 50 & \text { Avg. 123k }\end{array}$




\section{Number of Obtained References}

Annotation Avg. Sent. Avg. Number

\begin{tabular}{ccc} 
Interface & Length & of Refs. \\
\hline Prolog & 20.7 & $256 \mathrm{k}$ \\
Web & 23.3 & $49 \mathrm{k}$
\end{tabular}




\section{Number of Obtained References}

\begin{tabular}{ccc}
$\begin{array}{c}\text { Annotation } \\
\text { Interface }\end{array}$ & $\begin{array}{c}\text { Avg. Sent. } \\
\text { Length }\end{array}$ & $\begin{array}{c}\text { Avg. Number } \\
\text { of Refs. }\end{array}$ \\
\hline Prolog & 20.7 & $256 \mathrm{k}$ \\
Web & 23.3 & $49 \mathrm{k}$
\end{tabular}

- Prolog interface more efficient:

- Much less screen space taken by each bubble.

- Easier copying and modifications of bubbles. 


\section{Number of Obtained References}

\begin{tabular}{ccc}
$\begin{array}{c}\text { Annotation } \\
\text { Interface }\end{array}$ & $\begin{array}{c}\text { Avg. Sent. } \\
\text { Length }\end{array}$ & $\begin{array}{c}\text { Avg. Number } \\
\text { of Refs. }\end{array}$ \\
\hline Prolog & 20.7 & $256 \mathrm{k}$ \\
Web & 23.3 & $49 \mathrm{k}$
\end{tabular}

- Prolog interface more efficient:

- Much less screen space taken by each bubble.

- Easier copying and modifications of bubbles.

- About $5 \times$ more references per sentence were obtained in the 2 hours of annotation. 


\section{Similarity}

- For a given sentence and given MT system, we can measure similarity between candidate translation and one of the reference translations 


\section{Similarity}

- For a given sentence and given MT system, we can measure similarity between candidate translation and one of the reference translations

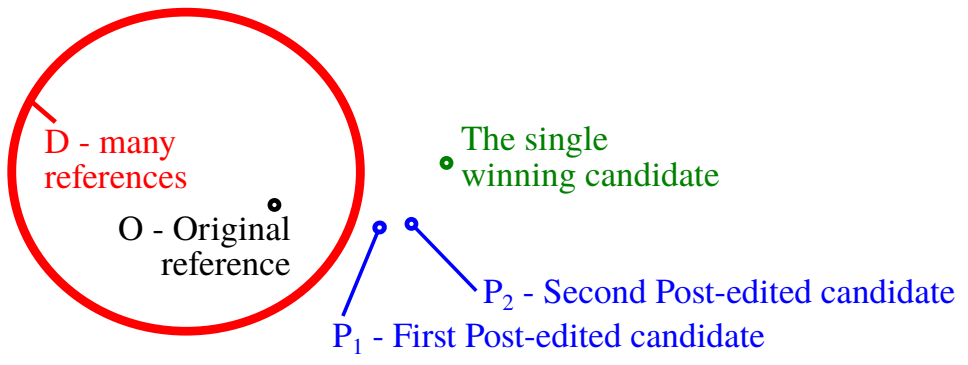




\section{Similarity}

- For a given sentence and given MT system, we can measure similarity between candidate translation and one of the reference translations

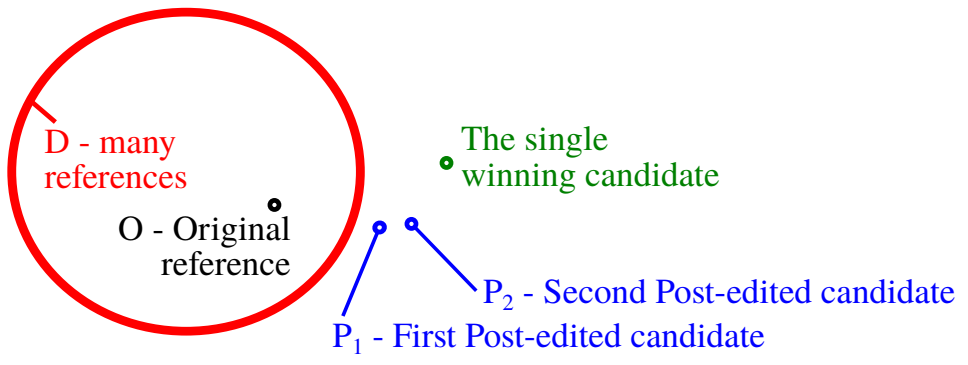

- We computed average similarity across all sentences and systems: 


\section{Similarity}

- For a given sentence and given MT system, we can measure similarity between candidate translation and one of the reference translations

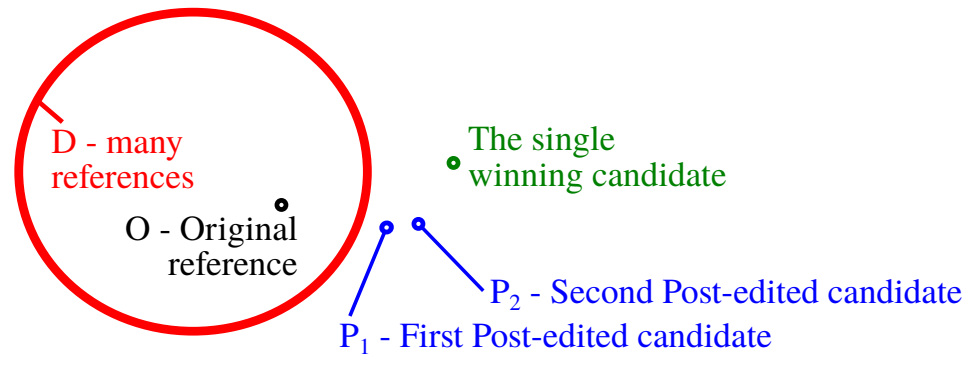

- We computed average similarity across all sentences and systems:

\section{Reference Set Similarity}




\section{Similarity}

- For a given sentence and given MT system, we can measure similarity between candidate translation and one of the reference translations

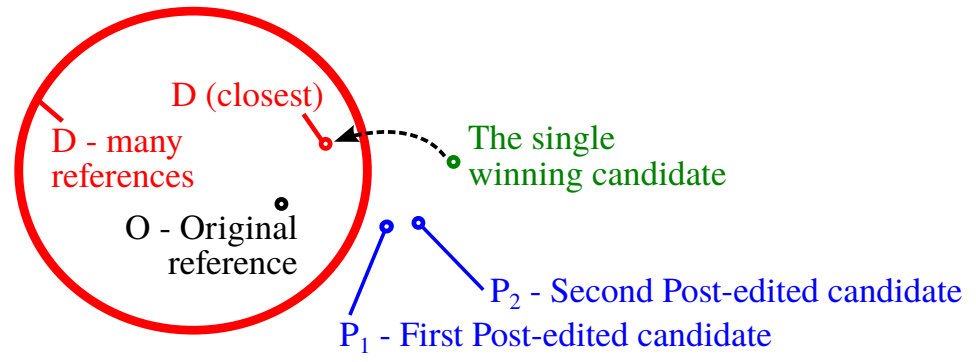

- We computed average similarity across all sentences and systems:

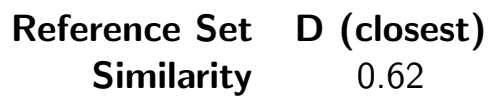




\section{Similarity}

- For a given sentence and given MT system, we can measure similarity between candidate translation and one of the reference translations

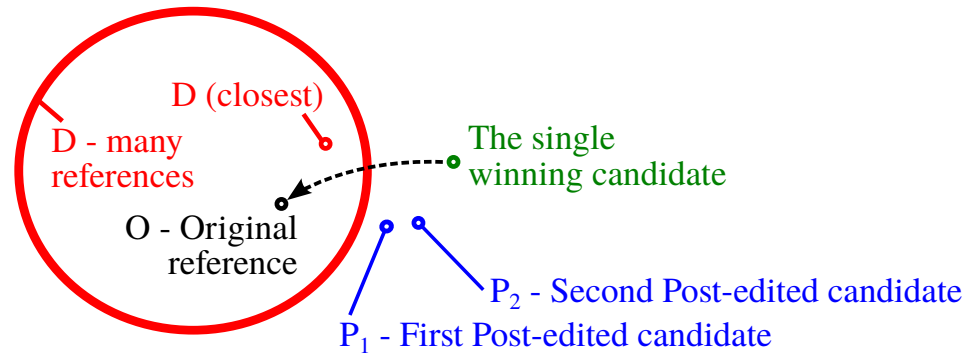

- We computed average similarity across all sentences and systems:

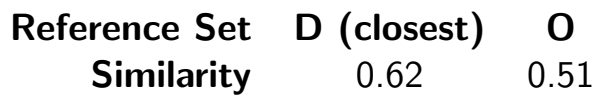




\section{Similarity}

- For a given sentence and given MT system, we can measure similarity between candidate translation and one of the reference translations

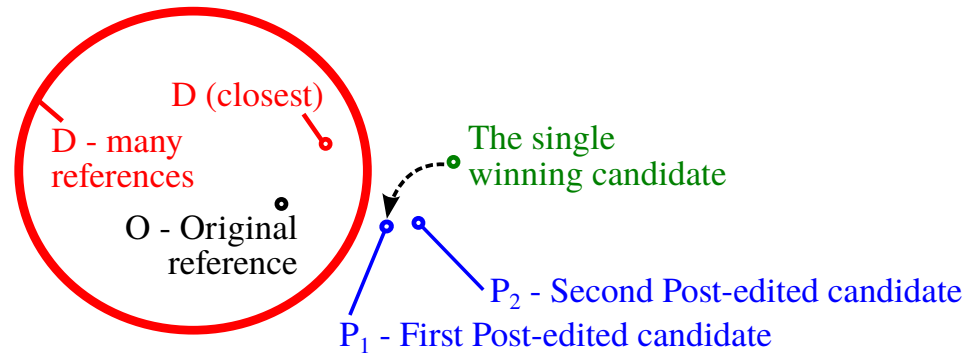

- We computed average similarity across all sentences and systems:
Reference Set
D (closest)
$\mathbf{0} \quad \mathbf{P}_{1}$ Similarity
0.62
$0.51 \quad 0.63$ 


\section{Similarity}

- For a given sentence and given MT system, we can measure similarity between candidate translation and one of the reference translations

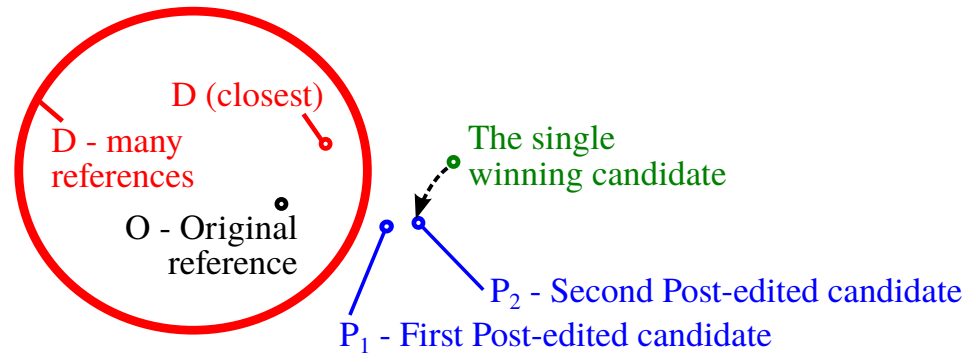

- We computed average similarity across all sentences and systems:
Reference Set
D (closest)
$\mathbf{0} \quad \mathbf{P}_{1}$
$\mathbf{P}_{2}$ Similarity
0.62
0.51
0.63
0.64 


\section{Example sentences}

- Src: Great when a film has several target groups, but a shame if they are mutually exclusive. 


\section{Example sentences}

- Src: Great when a film has several target groups, but a shame if they are mutually exclusive.

- Orig Ref: Je dobré, když má film více cílových skupin, je jen škoda, když se navzájem vylučují. 


\section{Example sentences}

- Src: Great when a film has several target groups, but a shame if they are mutually exclusive.

- Orig Ref: Je dobré, když má film více cílových skupin, je jen škoda, když se navzájem vylučují.

- Google: Skvěle, když film má několik cílových skupin, ale škoda, kdyby se navzájem vylučují. 


\section{Example sentences}

- Src: Great when a film has several target groups, but a shame if they are mutually exclusive.

- Orig Ref: Je dobré, když má film více cílových skupin, je jen škoda, když se navzájem vylučují.

- Google: Skvěle, když film má několik cílových skupin, ale škoda, kdyby se navzájem vylučují.

- D(closest to Google): Skvělé je, když film má několik cílových skupin, je ale škoda, když se tyto navzájem vylučují.

- D(farthest from Google): Výhodné je, pokud se snímek zaměřuje na víc cílových skupin, je jen smolné, pakliže jsou tyto skupiny vzájemně neslučitelné. 


\section{BLEU Correlations for Various Sets of References}

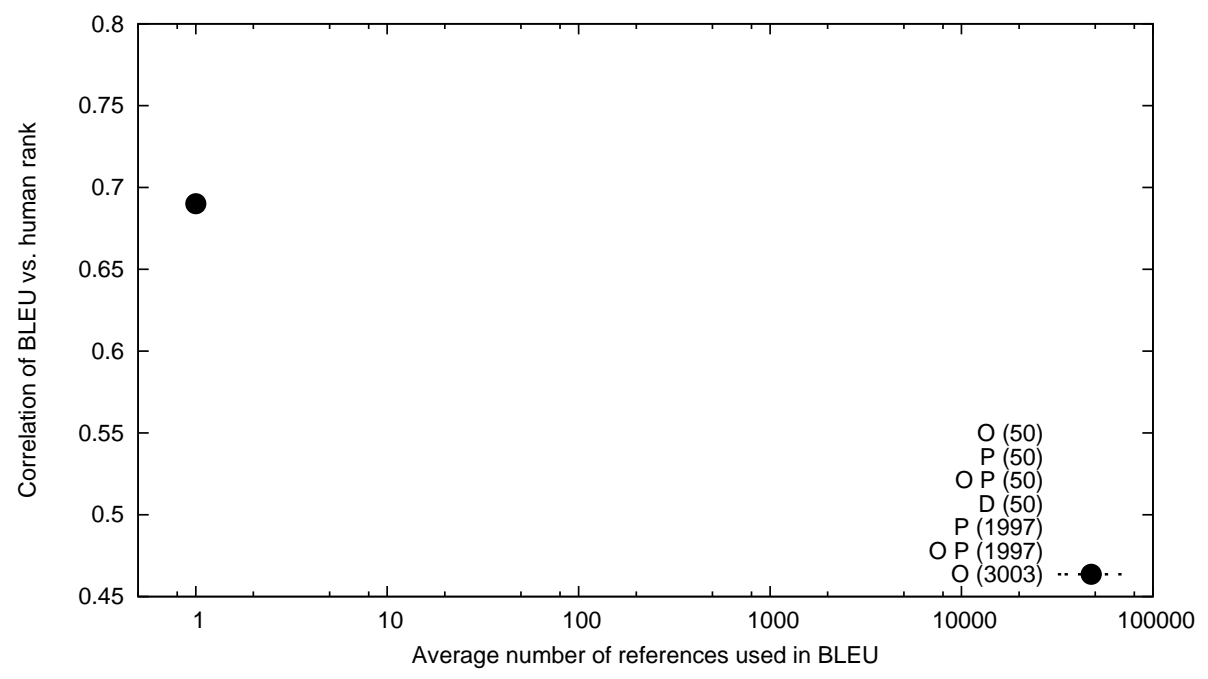




\section{BLEU Correlations for Various Sets of References}

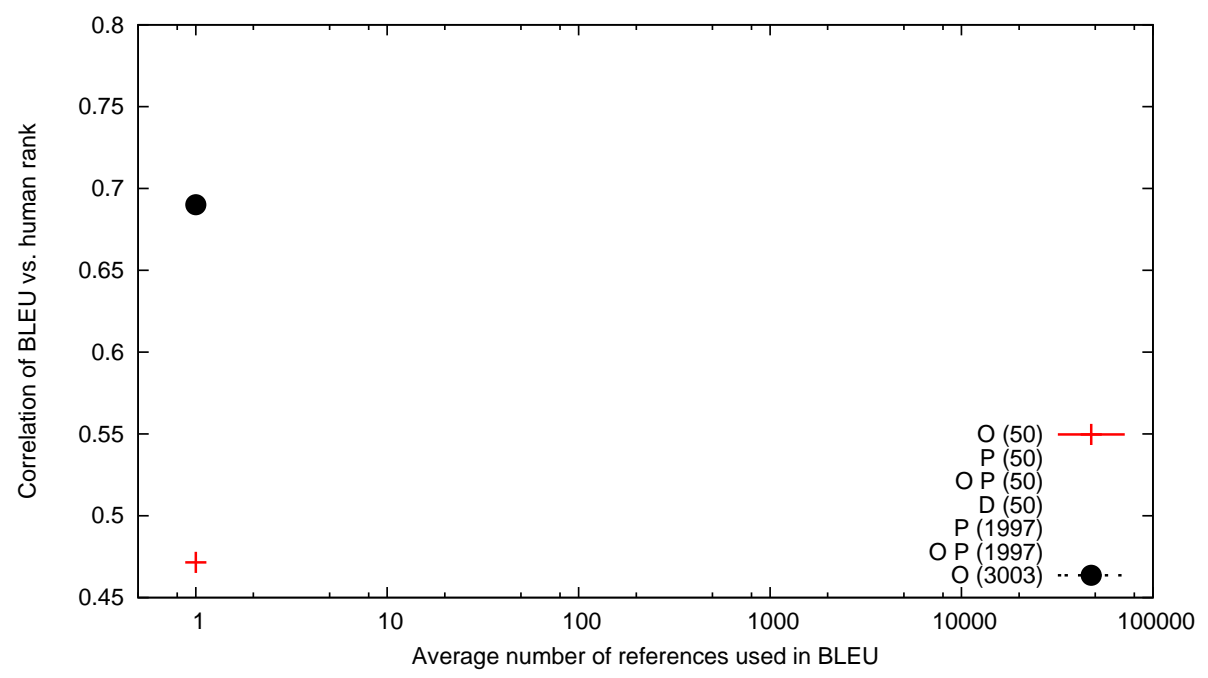




\section{BLEU Correlations for Various Sets of References}

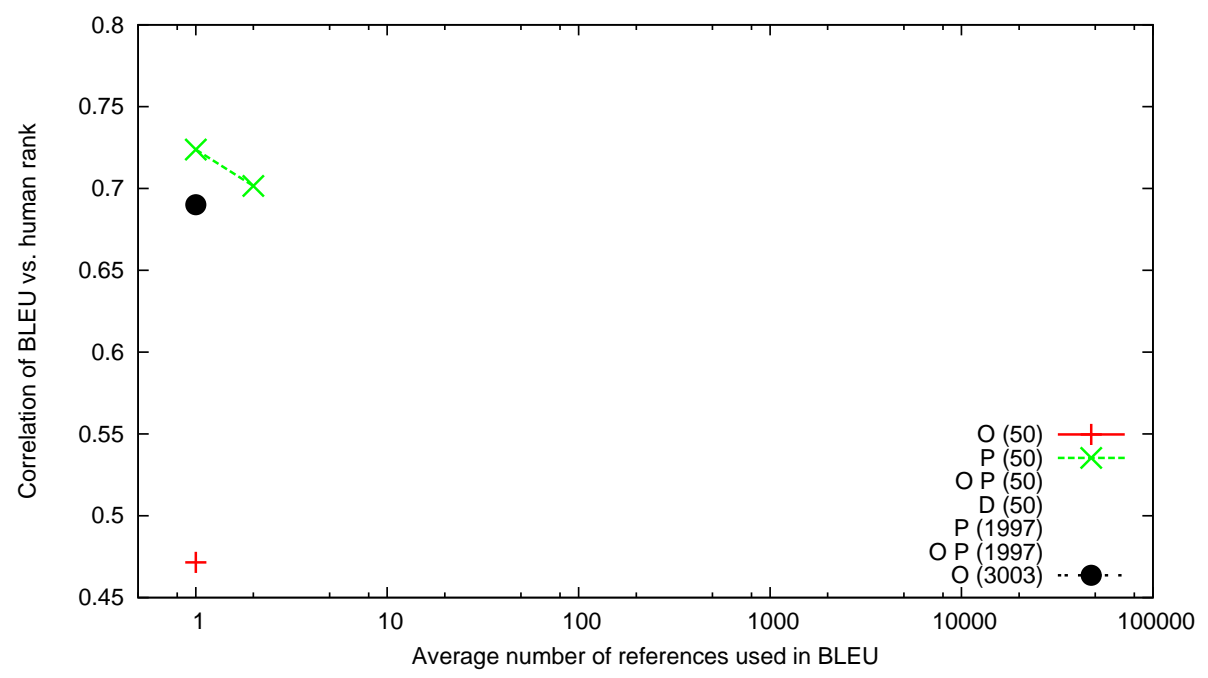




\section{BLEU Correlations for Various Sets of References}

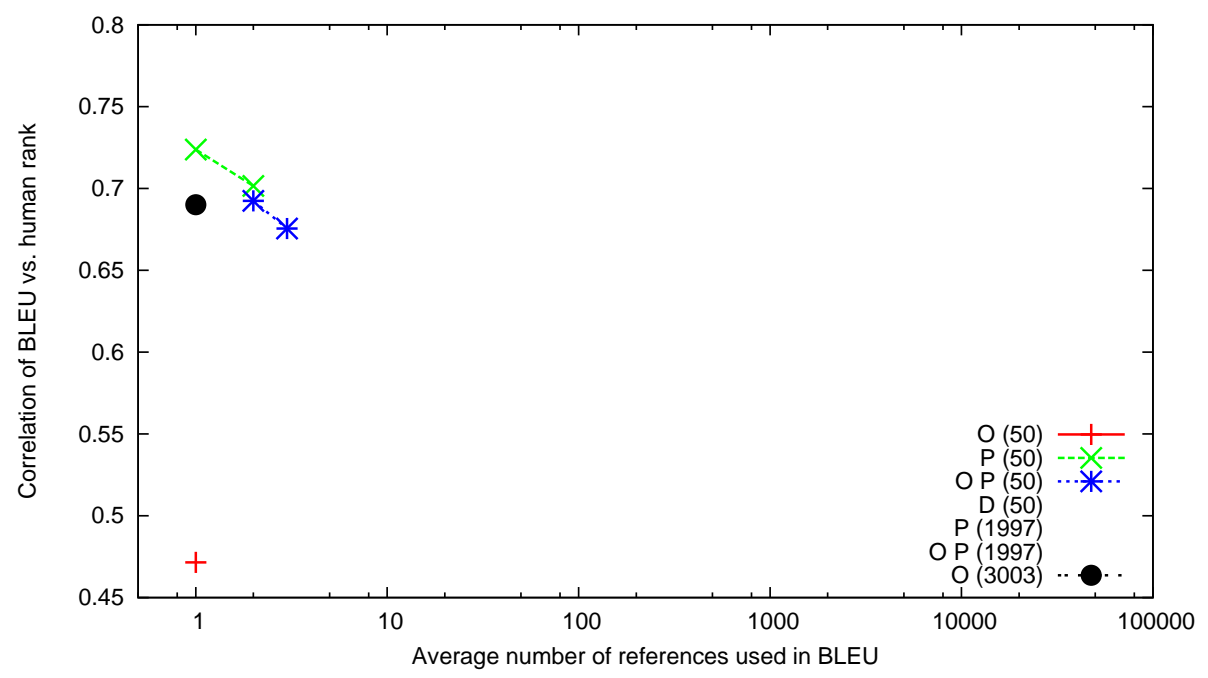




\section{BLEU Correlations for Various Sets of References}

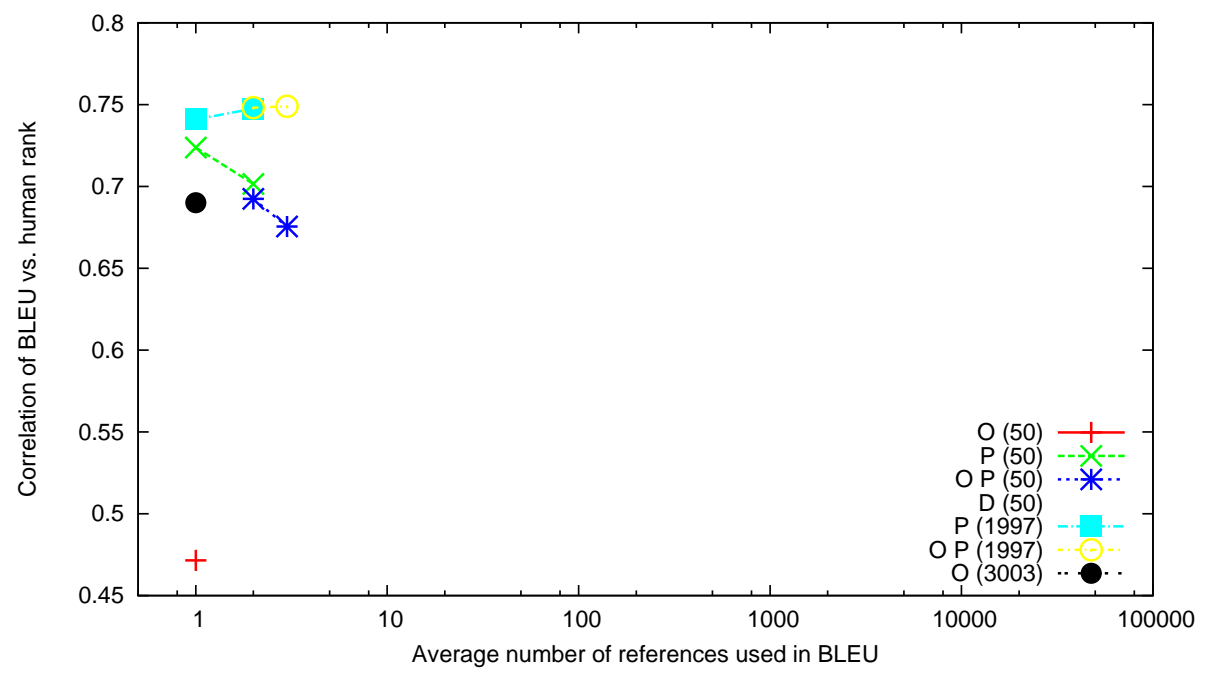




\section{BLEU Correlations for Various Sets of References}

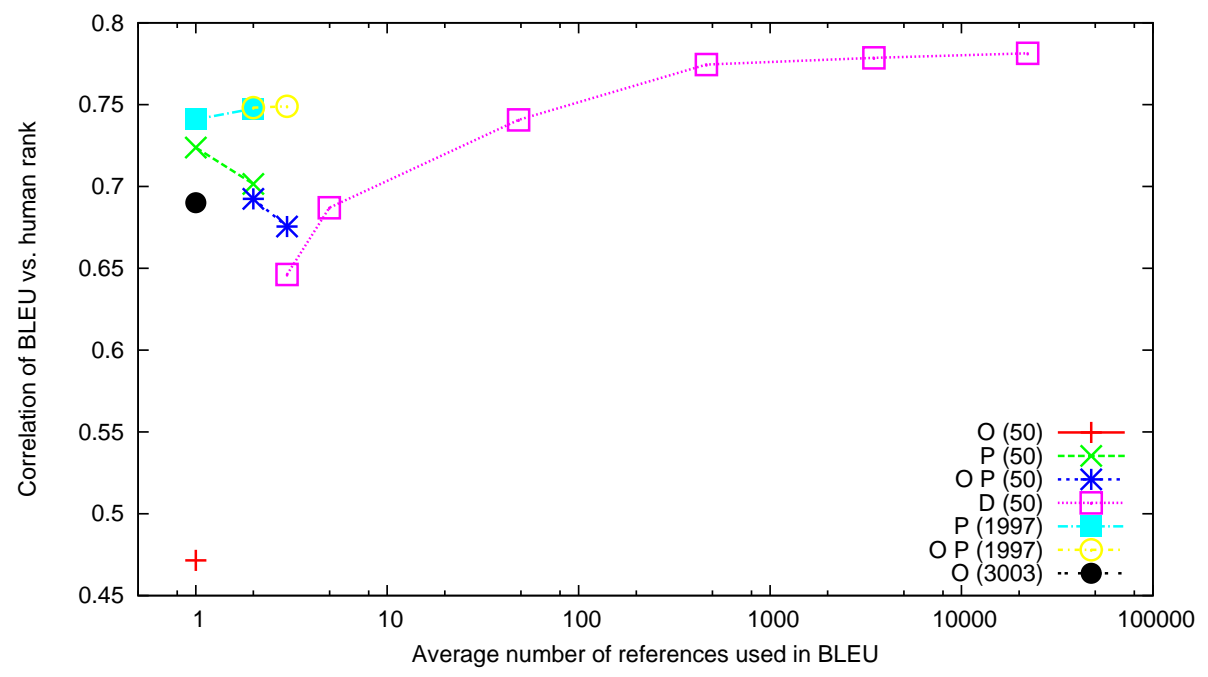




\section{Conclusion}

- Proposed a unification-based compact representation for many refs. 


\section{Conclusion}

- Proposed a unification-based compact representation for many refs. - Prolog interface more efficient than a web-based visual one. 


\section{Conclusion}

- Proposed a unification-based compact representation for many refs. - Prolog interface more efficient than a web-based visual one.

- It is common to obtain dozens of thousand reference translations. 


\section{Conclusion}

- Proposed a unification-based compact representation for many refs.

- Prolog interface more efficient than a web-based visual one.

- It is common to obtain dozens of thousand reference translations.

- Some of these references are as close to the MT output as the post-edited version of the sentence. 


\section{Conclusion}

- Proposed a unification-based compact representation for many refs.

- Prolog interface more efficient than a web-based visual one.

- It is common to obtain dozens of thousand reference translations.

- Some of these references are as close to the MT output as the post-edited version of the sentence.

- Post-edited MT output serves as a better reference than regular translations. 


\section{Conclusion}

- Proposed a unification-based compact representation for many refs.

- Prolog interface more efficient than a web-based visual one.

- It is common to obtain dozens of thousand reference translations.

- Some of these references are as close to the MT output as the post-edited version of the sentence.

- Post-edited MT output serves as a better reference than regular translations.

- Our many references allow for a better correlation between manual and automatic MT evaluation techniques, despite the low number of sentences in the test set. 